\title{
Tamarillo Consumption Associated with Increased Acetylcholinesterase Activity and Improved Oxidative Stress Markers in Farmers Exposed to Daily Pesticide-related Activities in Baturiti, Bali, Indonesia
}

\author{
Made Muliarta $^{1 *}$, Ketut Tirtayasa ${ }^{1}$, Putu Yuda Prabawa ${ }^{2,3}$, Kadek Adit Wiryadana ${ }^{4}$ \\ ${ }^{1}$ Department of Physiology, Faculty of Medicine, Universitas Udayana, Bali, Indonesia; ${ }^{2}$ Department of Clinical Pathology, \\ Faculty of Medicine, Universitas Udayana, Sanglah General Hospital, Bali, Indonesia; ${ }^{3}$ Master Program in Biomedicine, Faculty \\ of Medicine, Universitas Udayana, Bali, Indonesia; ${ }^{4}$ Clinical Clerkship, Faculty of Medicine, Universitas Udayana, Bali, Indonesia
}

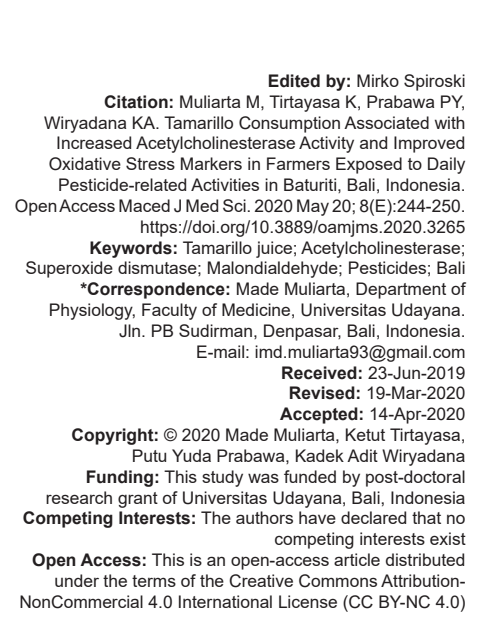

Introduction

Indonesia is a developing country which is also one of the largest agricultural countries in the world. Bali, as one among thousands of the small islands, also develops the agrarian sector as one of the main livelihoods of the population in addition to the tourism sector which has grown so rapidly. One type of agriculture in Bali is vegetable farming, which poses a significant risk of pesticides exposure [1]. Activities ranging from preparing and mixing, spraying, cleaning, and treating the leftover pesticides have a high chance of contacting toxic material through the skin/mucosal contact, inhalation, or even ingestion. The risk would even greater with poor adherent to principles of safety and health, which is, unfortunately, the norm for the most farmer on this island [2]. Research by the Hiperkes and Occupational Safety Center in Bali in collaboration with the Government Agriculture Service in 1998 found that the prevalence of mild poisoning was $20.32 \%$, moderate poisoning $4.25 \%$, and severe poisoning $0.18 \%$ [1]. In addition, Sutarga mentioned that the vegetable farmer with mild poisoning was found as high as $23 \%$ [3]. Government efforts to prevent/minimized the harmful effects of pesticides have long been carried out, but in reality, the use of pesticides among farmers is still far from safety standards [1], [3], [4].

The main content of pesticides, namely, organophosphates, has been widely known to be the main culprit of the negative effect on health. The main effect of organophosphate is the inhibition of the acetylcholinesterase (AChE) enzyme, which causes increased activity of acetylcholine as a neurotransmitter in synapse or neuromuscular junction [5]. The 
effects of toxicity may appear very quickly or up to several hours after entering the body. Severe acute poisoning manifests clinically as increased salivation, vomiting, tremors, and seizures [5], [6]. However, the inhibition of cholinesterase itself cannot explain for the wide range of disorders [7]. Pesticide, primarily organophosphate has been reported to induce oxidative stress through increased production of reactive oxygen species (ROS), hydrogen peroxide $\left(\mathrm{H}_{2} \mathrm{O}_{2}\right)$, nitrate $\left(\mathrm{NO}^{-}\right)$, and nitrite $\left(\mathrm{NO}^{-}\right)$[8], [9]. The presence of oxidative stress is characterized by increased plasma levels of malondialdehyde (MDA) and reduced erythrocyte superoxide dismutase (SOD) enzymes [10], [11], [12], [13].

Oxidative stress can be prevented or mitigated by various antioxidants [14], [15], [16]. Antioxidants can come from food or supplements (exogenous antioxidants) and also produced within the human body itself (endogenous antioxidants). Sources of antioxidants derived from food, generally derived from fruits. One of the fruits that are rich in antioxidants is tamarillo. ${ }^{17}$ Tamarillo or Dutch Eggplant (Cyphomandra betacea) is a commodity that was cultivated by several regions in Bali. At relatively low prices, this fruit is rich in antioxidants, including Vitamin C, Vitamin E, beta-carotene, anthocyanin, flavonol, phenolic acids, and other flavonoids [17]. These natural exogenous antioxidants could theoretically counter the effects of various free radicals [18].

The authors expect that the consumption of tamarillo fruit in the form of juice will be able to reduce oxidative stress in farmers who exposed to various activity related to the use of pesticide as the previous study [19]. Therefore, this study aimed to evaluate the effect of tamarillo consumption on the AChE activity and oxidative stress markers among farmers exposed to daily pesticide-related activity in Baturiti, Bali, Indonesia.

\section{Methods}

An experimental study with the randomized, open-label clinical trial design was conducted in the Baturiti, Tabanan Regency, Bali, Indonesia, during March-August 2018 period. This study involved 40 participants who randomly divided into two groups, groups of farmers without tamarillo juice supplementation (control), and groups of farmers who were given tamarillo juice every day for 2 weeks (intervention). Participants from both groups conduct their daily routine as usual, including pesticide relatedactivities without an appropriate personal protective device during the study period. The socio-demographic data of the participants were documented before the study began. All of the study protocol had been approved by the joint ethics committee of clinical study Universitas Udayana/Sanglah General Hospital, Denpasar, Bali, Indonesia (Letter no. 2017.03.1.0928).

Tamarillo juice was prepared from fresh fruits. The fruit was cleaned and washed to remove any residual compost using tap water. These were then cut into pieces and put on the blender with added water to produce a total volume of $250 \mathrm{ml}$. No additional sugar was added to the mixture. A preliminary study has been carried out to assess the bioactive components provided from tamarillo fruit from Biochemistry and Nutrition Laboratory, Faculty of Agricultural Technology, Universitas Udayana with number 07/Lab BN/VIII/2017.

The measurement of MDA, AChE, and SOD levels was carried out at the before and after the study period. The blood samples were taken from peripheral veins, stored in tubes at $0^{\circ} \mathrm{C}$ and immediately sent to the laboratory. The blood samples were analyzed in the Biochemical Laboratory of Universitas Gajah Mada, Yogyakarta, Indonesia.

Serum activity of AChE was assayed using high-performance liquid chromatography. MDA was measured by thiobarbituric acid reactive substances reaction in acidic medium, which on heating formed a pink complex that absorbed maximally at $532 \mathrm{~nm}$. The serum SOD activity was determined by the colorimetric method based on the ability of SOD to inhibit the autooxidation of epinephrine at a $\mathrm{pH}$ of 10.2. MDA and SOD were assessed in $\mathrm{nmol} / \mathrm{l}$, whereas $A C h E$ in $\mathrm{nmol} / \mathrm{min} / \mathrm{ml}$.

Demographic data and laboratory result were statistically analyzed. Continuous data were expressed as mean \pm standard deviation or median (minimummaximum) according to its distribution. The mean difference between the groups was analyzed using T-test or its non-parametric equivalent if it does not fulfill the requirement. Normality test conducted with Shapiro-Wilk and the homogeneity of variance was analyzed with the Levene test. Categorical data were expressed as a percentage and analyzed with Chisquare or Fisher's exact test. All statistical analysis conducted with SPSS for Windows version 17. The threshold of a significant difference is considered at $p<0.05$.

\section{Results}

The preliminary study on major bioactive substance from a crude extract of single tamarillo fruit is shown in Table 1.

A total of 32 participants were committed to the study protocol until the completion of the study protocol. Eight participants were dropped out of the study, one from the control groups and seven from the intervention groups. The study participants were 
mostly male $(84.37 \%)$ in both control $(78.94 \%)$ and intervention (92.31\%) groups (Table 2). The mean ages and the anthropometric measurement, including weight, height, and body mass index, were comparable for both groups ( $p>0.05)$. Most of the participants in the intervention group was graduated from elementary school $(46.15 \%)$ or did not attend any formal education $(42.11 \%)$ in the control group. The participants

Table 1: Bioactive compound assessment on a single tamarillo fruit

\begin{tabular}{lll}
\hline Parameters & Methods & Unit \\
\hline Flavonoid & Spectrophotometry & $4.33 \mathrm{mg} / 100 \mathrm{QE} \mathrm{bb}$ \\
Tocopherol & Spectrophotometry & $4.61 \mathrm{mg} / 100 \mathrm{~g} \mathrm{bb}$ \\
Polyphenol & Spectrophotometry & $71.92 \mathrm{mg} / 100 \mathrm{~g}(\mathrm{GAE}) \mathrm{bb}$ \\
$\beta$-carotene & Spectrophotometry & $628.625 \mathrm{mg} / 100 \mathrm{~g} \mathrm{bb}$ \\
Ascorbic acid (Vitamin C) & Titrimetric & $31.02 \mathrm{mg} / 100 \mathrm{~g} \mathrm{bb}$ \\
Citric acid & Titrimetric & $2.55 \% \mathrm{bb}$ \\
Anthocyanin & Spectrophotometry & $0.98 \mathrm{mg} / 100 \mathrm{~g} \mathrm{bb}$ \\
Water level & Gravimetry & $83.79 \% \mathrm{bb}$ \\
Ash level & Gravimetry & $1.01 \% \mathrm{bb}$ \\
Lipid & Soxhletation & $2.94 \% \mathrm{bb}$ \\
Protein & Titrimetric & $1.11 \% \mathrm{bb}$ \\
Carbohydrate & By difference & $11.15 \% \mathrm{bb}$ \\
Calorie & Calculation & $75.52 \mathrm{kcal}$ \\
\hline
\end{tabular}

of the study had become a farmer for two decades, with the majority of its land were owned by themselves in both control (52.63\%) and intervention (61.54\%) groups. The area of lands occupied was varied, with mostly owned, some rented, or in combination. On average, the control $\left(2500[400-27,500] \mathrm{m}^{2}\right)$ and intervention (2750 [100-25,000] $\mathrm{m}^{2}$ ) groups showed a comparable median of land area $(p=0.948)$ (Table 2$)$. The median frequency of spraying pesticide was 2 times a week, with a median duration of an hour each, which also comparable for both groups ( $p>0.05)$ (Table 2). Furthermore, no differences in the distribution of smoking habit during spraying were observed ( $p=0.961)$. The baseline characteristic of the study participant is summarized in Table 2.

The result of laboratory measurement of each biomarker at pre-study and post-study is shown in Table 3. Our study found that the post-study SOD level was significantly increase in the intervention group $(57.96 \pm 12.84 \mathrm{nmol} / \mathrm{l})$ compared with control group $(38.23 \pm 7.87 \mathrm{nmol} / \mathrm{l})(\mathrm{p}<0.0001)$. There was a significant reduce of post-study MDA level in the intervention group $(27.27 \pm 3.42 \mathrm{nmol} / \mathrm{l})$ compared with control group $(110.73 \pm 9.68 \mathrm{nmol} / \mathrm{l})(\mathrm{p}=0.003)$ (Table 3 ). In addition, a significant increase of poststudy AChE level was found in the intervention group $(375.15 \pm 209.99 \mathrm{nmol} / \mathrm{min} / \mathrm{ml})$ compared with control group $(30.06 \pm 4.74 \mathrm{nmol} / \mathrm{min} / \mathrm{ml})(p<0.0001)$ (Table 3$)$.

\section{Discussion}

Toxic effect of pesticide on both animals and humans has long been established [18], [19], [20].

Table 2: Baseline characteristics of study respondents

\begin{tabular}{|c|c|c|c|c|c|}
\hline \multirow[t]{2}{*}{ Variables } & \multicolumn{2}{|l|}{ Control group $(n=19)$} & \multicolumn{2}{|l|}{ Intervention group $(n=13)$} & \multirow[t]{2}{*}{$\mathrm{p}$-value } \\
\hline & Mean \pm SD or median (min-max) & $\mathrm{n}(\%)$ & Mean \pm SD or median (min-max) & $n(\%)$ & \\
\hline \multicolumn{6}{|l|}{ Gender (\%) } \\
\hline Male & & $15(78.94)$ & & $12(92.31)$ & $0.625^{\mathrm{a}}$ \\
\hline Female & & $4(21.06)$ & & $1(7.69)$ & \\
\hline Age (years) & $47.16 \pm 11.16$ & & $45.38 \pm 10.06$ & & $0.650^{\mathrm{b}}$ \\
\hline Height $(\mathrm{m})$ & $1.64 \pm 0.06$ & & $1.63 \pm 0.06$ & & $0.739^{b}$ \\
\hline Weight (kg) & $60.58 \pm 10.82$ & & $61.34 \pm 7.72$ & & $0.830^{\mathrm{b}}$ \\
\hline Body mass index & $22.29 \pm 3.42$ & & $22.84 \pm 2.72$ & & $0.631^{\mathrm{b}}$ \\
\hline \multicolumn{6}{|l|}{ Level of education (\%) } \\
\hline Elementary School & & $6(31.58)$ & & $6(46.15)$ & \\
\hline Junior High School & & $4(21.05)$ & & $1(7.69)$ & \\
\hline Senior High School & & $1(5.26)$ & & $3(23.08)$ & \\
\hline Bachelor Degree & & $0(0.00)$ & & $0(0.00)$ & \\
\hline Not Graduated & & $8(42.11)$ & & $3(23.08)$ & \\
\hline \multicolumn{6}{|l|}{ Land ownership } \\
\hline Owned & & $10(52.63)$ & & $8(61.54)$ & \\
\hline Rent & & $4(21.05)$ & & $2(15.38)$ & \\
\hline Combination & & $5(26.32)$ & & $3(23.08)$ & \\
\hline Land area $\left(\mathrm{m}^{2}\right)$ & $2500(400-27,500)$ & & $2750(100-25,000)$ & & $0.948^{\mathrm{c}}$ \\
\hline Duration being farmer (years) & $20.53 \pm 10.91$ & & $21.92 \pm 9.44$ & & $0.710^{\mathrm{b}}$ \\
\hline Spray frequency (times/week) & $2(1-4)$ & & $2(2-3)$ & & $0.448^{\mathrm{c}}$ \\
\hline Duration of spraying (hs) & $1(0.25-2)$ & & $1(0.30-3)$ & & $0.596^{\mathrm{C}}$ \\
\hline \multicolumn{6}{|l|}{ Smoking (\%) } \\
\hline Yes & & $6(31.57)$ & & $4(30.77)$ & $0.961^{\mathrm{a}}$ \\
\hline No & & $13(68.43)$ & & $9(69.23)$ & \\
\hline
\end{tabular}

Table 3: The SOD, MDA, and AChE levels comparison between pre- and post-study

\begin{tabular}{|c|c|c|c|c|c|}
\hline \multirow{2}{*}{ Parameter } & \multirow{2}{*}{ Classification } & \multicolumn{3}{|c|}{ Between groups difference } & \multirow{2}{*}{$p$-value ${ }^{d}$} \\
\hline & & Control (mean \pm SD) & Intervention (mean \pm SD) & 95\% Clc (Lower-Upper) & \\
\hline \multirow[t]{4}{*}{ SOD } & Pre-study & $38.70 \pm 15.77$ & $34.54 \pm 11.94$ & $(14.13-32.49)$ & $<0.0001$ \\
\hline & Post-study & $38.23 \pm 7.87$ & $57.96 \pm 12.84$ & & \\
\hline & Mean Difference $\mathrm{a}^{a}$ & $-0.45 \pm 17.57$ & $23.31 \pm 15.89$ & & \\
\hline & $p$-value ${ }^{\text {b }}$ & 0.887 & $<0.0001$ & & \\
\hline \multirow[t]{4}{*}{ MDA } & Pre-study & $112.18 \pm 43.63$ & $109.09 \pm 63.34$ & $(45.76-117.88)$ & 0.003 \\
\hline & Post-study & $110.73 \pm 9.68$ & $27.27 \pm 3.42$ & & \\
\hline & Mean difference ${ }^{a}$ & $-1.45 \pm 41.60$ & $-81.82 \pm 62.45$ & & \\
\hline & $p$-value ${ }^{b}$ & 0.917 & $<0.0001$ & & \\
\hline \multirow[t]{4}{*}{ AChE } & Pre-study & $31.93 \pm 5.64$ & $33.54 \pm 4.41$ & $(222.41-460.80)$ & $<0.0001$ \\
\hline & Post-study & $30.06 \pm 4.74$ & $375.15 \pm 209.99$ & & \\
\hline & Mean difference ${ }^{a}$ & $-1.87 \pm 5.68$ & $341.61 \pm 206.44$ & & \\
\hline & p-value ${ }^{b}$ & 0.193 & $<0.0001$ & & \\
\hline
\end{tabular}


The behavior of pesticide use that does not meet the standards will increase the risk of pesticide intoxication among farmers. The WHO estimates 250,000 deaths occur among 3 million cases of pesticide poisoning every year [21]. Organophosphate pesticide intoxication has been mainly attributed to inhibition of cholinesterase activity. Most farmers have experienced symptoms of poisoning after spraying, such as headaches, nausea, eye irritation, and tremors [3]. However, the inhibition of cholinesterase itself cannot explain for the wide range of disorders, especially in the case of chronic exposure in subclinical dose [7], [18]. Based on those mentioned above, several biomarkers have been elucidated to determine the effect of organophosphate on health, risk of malignancy, and metabolic diseases [22], [23], [24]. So that, the recent studies start to shift focus on other long-term effects of the pesticide such as the oxidative stress as well as the cholinesterase activity among farmers who are more vulnerable to the daily-pesticide exposure. Pesticide, primarily organophosphate containing compound, has been reported increase the production of ROS including $\mathrm{H}_{2} \mathrm{O}_{2}, \mathrm{NO}^{-}$, and $\mathrm{NO}^{-}$, which collectively caused a state of increased oxidative stress [8]. When exposure to pesticide persists for a long time, the antioxidant sources can be depleted [25].

Oxidative stress depleted our antioxidant activity, primarily decrease in some enzyme which acts as an endogenous antioxidant. Damage induced by oxidative stress primarily occurs through the production of ROS, which involves "stealing" electrons from nucleic acids, lipids, and proteins, leading to the altered function and structure within the cells [26], [27]. Antioxidants can protect cells from damage caused by ROS and RNS [15]. If the body is exposed to large amounts of ROS, then the level of an endogenous antioxidant such as SOD will decrease [28]. SOD is an enzyme that plays a role in repairing cells and reducing cell damage caused by superoxide radicals. The activity of SOD in individuals with high oxidant exposure is significantly lower compared with that in healthy persons, which probably fuel the development of oxidative stress-related health problems [25]. On the other hand, oxidative stress allows lipid peroxidation in cell membranes with the resulting MDA can be measured in plasma [11], [12]. In fact, MDA is one of the most widely used biomarkers and is suitable for lipid peroxidation among reactive aldehydes [13]. The previous study has confirmed that patients with pesticide intoxication also showed an increased MDA level [10]. Thus, the presence of oxidative stress is characterized by reduced erythrocyte superoxide dismutase (SOD) enzymes and increased plasma levels of MDA.

This study shows that supplementation of tamarillo juice showed significantly higher SOD and AChE, but lower MDA as compared to the control group. This result supports the previous study of Surajudeen et al. and Vidyasagar et al. Both studies also reported low AChE and SOD activity on the pesticide-exposed worker [9], [19]. Numerous studies have shown that AChE was reduced in farmer exposed to pesticide [29], [30], [31], [32], [33], [34], [35], [36], [37], [38]. Our study also showed a similar result, which further emphasizes that lower AChE is a common feature in pesticideexposed individuals. AChE has been used for years as the biomarker of neurotoxicity from environmental and occupational exposure of organophosphorus and related compounds. It is a sensitive indicator of chronic exposure due to low recovery rate, therefore, shows cumulative inhibitory effect, and it mirrors the biological effect of the central nervous systems variant of AChE. AChE thus far showed as useful biomarkers as it easy to measure, show a dose-dependent characteristic to exposure level, and exhibits a link to clinically significant adverse effect [39], [40]. However, there is still no single range of value or consensus criteria for defining chronic exposure case.

The previous study also found that pesticide intoxication showed a negative correlation between the levels of cholinesterase and MDA. Meanwhile, positive correlations were found between cholinesterase and catalase and glutathione, which the latter two were endogenous antioxidants [41]. In this study, the antioxidants enzyme activities of SOD were lower in the control group. Decrease of the antioxidant enzyme may be related to rapid consumption and exhaustion of storage of this enzyme in combating free radicals generated due to pesticide exposure. Besides, activities of other major antioxidant enzymes may also be inadequate. A similar condition was also observed in condition with increased exposure to free radical [9]. The observed higher level of MDA in the intervention group compared with control in this study might suggest increased lipid peroxidation in the latter. This indicates that the higher MDA level will lead to the higher the risk of tissue damage due to oxidative stress.

Overall, our result of 2 weeks of tamarillo juice supplementation showed a positive increment of antioxidants enzyme. The biological mechanisms are not entirely clear but may be attributed to the singular or synergistic action of several bioactive compounds. Tamarillo contains several types of antioxidants, including Vitamin C, Vitamin E, betacarotene, anthocyanin, flavonol, phenolic acids, and other flavonoids [42]. These natural exogenous antioxidants could theoretically counter the effects of various free radicals, such as hydroxyl radicals, superoxide anions, peroxy lipid radicals, nitric oxide, singlet oxygen, and peroxynitrite [17]. A large amount of evidence shows that bioactive compounds such as carotenoids, flavonoids, phytoestrogens, and dietary fiber, which are present in a wide variety of fruits and vegetables, might reduce oxidative stress and inflamation [43], [44], [45], [46], [47], [48], [49]. Tamarillo has been demonstrated to a contained variety 
of phenolic composition [50]. Polyphenols are capable of neutralizing reactive species, due to their favorable number and position of hydroxyls. Dietary nutrients rich in polyphenols (e.g. flavonoid) could play an important role in the prevention of biochemical alteration due to oxidative stress, perhaps through its role in increasing the circulation of antioxidant compounds [25].

Tamarillo fruits are considerably nutritious because of its high content of vitamin, phytochemicals including beta-carotene anthocyanins, flavonols, phenolic acids, and large amounts of ascorbic acid [50], [51]. This fruit is rich in antioxidants at relatively low prices; however, the public does not widely acknowledge the positive effect on the various system, both related and unrelated to the antioxidant activity. To date, tamarillo remains unexplored, to the best of our knowledge; this is the first study to evaluate the protective effects of tamarillo on farmer who highly exposed to environmental pollutant like pesticide. Throughout the study period, there were no toxic signs such as vomiting, diarrhea, or constipation detected in the intervention group. Therefore, it could be considered safe. We acknowledge that this study has several limitations. This study was not designed to detect difference level of the effect associated with any type of pesticide nor its specific substance that known to inhibit AChE such as organophosphates or carbamates directly. Therefore, we cannot provide the answer to whether tamarillo could decrease the negative effect of organophosphate better than organocarbamate or vice versa. In addition, this was a preliminary study, thus further study with a larger participant and a more extended period of intervention needed to confirm the result.

\section{Conclusion}

Tamarillo consumption showed its potential to protect the body from oxidative stress. In this study, tamarillo associated with increased SOD and the decrements of oxidative stress biomarkers MDA as well as normalization of serum AChE. Therefore, consumption of tamarillo on a daily basis can be recommended as prevention of oxidative stress-related to chronic pesticide exposure.

\section{Acknowledgments}

The authors would like to acknowledge the honorable professors and seniors in Udayana University for their full support and to all farmers in Baturiti, who participate in this study.

\section{Authors' Contributions}

IMM and KT are responsible for the conceptual framework, data gathering, interpreting the results, draft and approving the final manuscript. IPYP and KAW are responsible for statistical analysis and English writing of the manuscript.

\section{References}

1. Purnawati S. Pendekatan ergonomi total untuk mengantisipas risiko keracunan pestisida pada petani-petani bali. Bumi Lestari J Environ. 2008;8(2):154-61.

2. Damalas CA, Eleftherohorinos IG. Pesticide exposure, safety issues, and risk assessment indicators. Int $\mathrm{J}$ Environ Res Public Health. 2011;8(5):1402-19. https://doi.org/10.3390/ ijerph8051402

PMid:21655127

3. Sutarga IM. Pencegahan efek pestisida pada petani di desa buahan kintamani. Bul Udayana Mengabdi. 2012;6(1):1-6.

4. Muliarta IM. Pelatihan Pestisida di Kabupaten Tabanan. Denpasar: Yayasan IImu faal Denpasar; 2007.

5. Asghar U, Malik M, Javed A. Pesticide Exposure and Human Health: A Review. J Ecosyst Ecography. 2016;S5:5.

6. Eddleston M, Buckley NA, Eyer P, Dawson AH. Management of acute organophosphorus pesticide poisoning. Lancet. 2008;371(9612):597-607. s0140-6736(07)61202-1 https://doi.org/10.1016/ PMid:17706760

7. Peeples ES. Albumin, a new biomarker of organophosphorus toxicant exposure, identified by mass spectrometry. Toxicol Sci. 2005;83(2):303-12. https://doi.org/10.1093/toxsci/kfi023 PMid:15525694

8. Mehta A, Verma RS, Srivastava N. Chlorpyrifos induced alterations in the levels of hydrogen peroxide, nitrate and nitrite in rat brain and liver. Pestic Biochem Physiol. 2009;94(2-3):559. https://doi.org/10.1016/j.pestbp.2009.04.001

9. Vidyasagar J, Karunakar N, Reddy MS, Rajnarayana K Surender T, Krishna DR. Oxidative stress and antioxidant status in acute oxidative stress and antioxidant status in acute organophosphorous insecticide poisoning. Indian J Pharmacol. 2004;36(2):76-9.

10. Mishra B, Badade Z, Rastogi S, Singh S. Antioxidant status and oxidative stress in organophosphate pesticide poisoning. IOSR J Dent Med Sci. 2013;7(6):20-4

11. Lieberman M, Peet A. Marks' Basic Medical Biochemistry A Clinical Approach. $5^{\text {th }}$ ed. Philadelphia, PA: Wolters Kluwer, Lippincott Williams \& Wilkins; 2017.

12. Halliwell B, Gutteridge JM. Free Radicals in Biology and Medicine. London: Oxford University Press; 2015.

13. Saxens R, Lal AM, Semadi N. Effect of aging on antioxidant enzyme status and lipid peroxidation. J Indian Acad Geriatr. 2015;2(2):53-6

14. Eberhardt MK. Reactive Oxygen Metabolites: Chemistry and Medical Consequences. Boca Raton: CRC Press; 2001. p. 591.

15. Banjarnahor SD, Artanti N. Antioxidant properties of flavonoids. Med J Indones. 2015;23(4):239. https://doi.org/10.13181/mji. v23i4. 1015

16. Ray PD, Huang BW, Tsuji Y. Reactive oxygen species (ROS) 
homeostasis and redox regulation in cellular signaling. Cell Signal. 2012;24(5):981-90. https://doi.org/10.1016/j. cellsig.2012.01.008

PMid:22286106

17. Lister CE, Morrison SC, Kerkhofs NS, Wright, MK. The Nutritional Composition and Health Benefits of New Zealand Tamarillos. Wellington: Crop and Food Research; 2011.

18. Alavanja MC, Hoppin JA, Kamel F. Health effects of chronic pesticide exposure: Cancer and neurotoxicity. Annu Rev Public Health. 2004;25(1):155-97. https://doi.org/10.1146/annurev. publhealth.25.101802.123020

PMid: 15015917

19. Surajudeen YA, Sheu RK, Ayokulehin KM, Olatunbosun AG. Oxidative stress indices in Nigerian pesticide applicators and farmers occupationally exposed to organophosphate pesticides. Int J Appl Basic Med Res. 2014;4(1):S37-40. https://doi. org/10.4103/2229-516x.140730 PMid:25298941

20. Calvert GM, Karnik J, Mehler L, Beckman J, Morrissey B, SievertJ, et al. Acute pesticide poisoning among agricultural workers in the United States, 1998-2005. Am J Ind Med. 2008;51(12):883-98. https://doi.org/10.1002/ajim.20623 PMid: 18666136

21. Yang CC, Deng JF. Intermediate syndrome following organophosphate insecticide poisoning. J Chin Med Assoc. 2007;70(11):467-72.

PMid: 18063499

22. Lerro CC, Koutros S, Andreotti G, Friesen MC, Alavanja MC, Blair A, et al. Organophosphate insecticide use and cancer incidence among spouses of pesticide applicators in the Agricultural health study. Occup Environ Med. 2015;72(10):73644. https://doi.org/10.1136/oemed-2014-102798

PMid:26150671

23. Prabawa IP, Bharghah A, Liwang F, Tandio DA, Tandio AL, Lestari AA, et al. Pretreatment neutrophil-to-lymphocyte ratio (NLR) and platelet-to-lymphocyte ratio (PLR) as a predictive value of hematological markers in cervical cancer. Asian Pac J Cancer Prev. 2019;20(3):863-8. https://doi.org/10.31557/ apjcp.2019.20.3.863

PMid:30912405

24. Mulyani WR, Sanjiwani MI, Sandra, Prabawa IPY, Lestari AAW, Wihandani DM, et al. Chaperone-based therapeutic target innovation: Heat shock protein 70 (HSP70) for Type 2 diabetes mellitus. Diabetes Metab Syndr Obes. 2020;13:559-68. https:// doi.org/10.2147/dmso.s232133

PMid:32161482

25. Bjørling-Poulsen M, Andersen HR, Grandjean P. Potential developmental neurotoxicity of pesticides used in Europe. Environ Health. 2008;7:50. https://doi.org/10.1186/1476-069x-7-50 PMid: 18945337

26. Kadir NA, Rahmat A, Jaafar HZ. Protective effects of tamarillo (Cyphomandra betacea) extract against high fat diet induced obesity in sprague-dawley rats. J Obes. 2015;2015:846041. https://doi.org/10.1155/2015/846041

27. Aly N, Kawther M, El-Sebae F, Khalek A. Protective Effect of Vitamin C Against Chlorpyrifos Oxidative Stress in Male Mice. Amsterdam: Elsevier; 2010. https://doi.org/10.1016/j. pestbp.2009.11.007

28. Ambardini RL. Efek Pemberian Panax Ginseng Terhadap Kadar Malondialdehyde (MDA) dan Superoxide Dismutase (SOD) Darah Pada Latihan Fisik Aerobik Intensitas Sedang. Yogyakarta: Gajah Mada University; 2005. https://doi. org/10.33757/jik.v2i2.92

29. von Osten JR, Tinoco-Ojanguren $R$, Soares $A M$, Guilhermino L, Guilhermino L. Effect of pesticide exposure on acetylcholinesterase activity in subsistence farmers from
Campeche, Mexico. Arch Environ Health. 2004;59(8):418-25. https://doi.org/10.3200/aeoh.59.8.418-425

PMid:16268118

30. Kapeleka JA, Sauli E, Sadik O, Ndakidemi PA. Biomonitoring of acetylcholinesterase (AChE) activity among smallholder horticultural farmers occupationally exposed to mixtures of pesticides in Tanzania. J Environ Public Health. 2019;2019:1 11. https://doi.org/10.1155/2019/3084501

31. Dasgupta S, Meisner C, Wheeler D, Xuyen K, Lam NT. Pesticide poisoning of farm workers-implications of blood test results from Vietnam. Int J Hyg Environ Health. 2007;210(2):121-32. https:// doi.org/10.1596/1813-9450-3624

PMid: 17008128

32. Neupane D, Jørs E, Brandt L. Pesticide use, erythrocyte acetylcholinesterase level and self-reported acute intoxication symptoms among vegetable farmers in Nepal: A crosssectional study. Environ Health. 2014;13(1):98. https://doi. org/10.1186/1476-069x-13-98 PMid:25409889

33. Guytingco A, Thepaksorn P, Neitzel RL. Prevalence of abnormal serum cholinesterase and associated symptoms from pesticide exposure among agricultural workers in the South of Thailand. J Agromedicine. 2018;23(3):270-8. https://doi.org/10.1080/1059 924x.2018.1470049

PMid: 30047860

34. Rathish D, Senavirathna I, Jayasumana C, Agampodi S. Red blood cell acetylcholinesterase activity among healthy dwellers of an agrarian region in Sri Lanka: A descriptive cross-sectional study. Environ Health Prev Med. 2018;23(1):25. https://doi. org/10.1186/s12199-018-0717-0

PMid:29929492

35. Singh S, Kumar V, Thakur S, Banerjee BD, Chandna S, Rautela RS, et al. DNA damage and cholinesterase activity in occupational workers exposed to pesticides. Environ Toxicol Pharmacol. 2011;31(2):278-85. https://doi.org/10.1016/j. etap.2010.11.005

PMid:21787695

36. Koureas M, Tsakalof A, Tzatzarakis M, Vakonaki E, Tsatsakis A, Hadjichristodoulou C. Biomonitoring of organophosphate exposure of pesticide sprayers and comparison of exposure levels with other population groups in Thessaly (Greece). Occup Environ Med. 2014;71(2):126-33. https://doi.org/10.1136/ oemed-2013-101490

PMid:24186943

37. Safi JM, Mourad TA, Yassin MM. Hematological biomarkers in farm workers exposed to organophosphorus pesticides in the Gaza Strip. Arch Environ Occup Health. 2005;60(5):235-41. https://doi.org/10.3200/aeoh.60.5.235-241

PMid: 17290843

38. Simoniello MF, Kleinsorge EC, Scagnetti JA, Mastandrea C, Grigolato RA, Paonessa AM, et al. Biomarkers of cellular reaction to pesticide exposure in a rural population. Biomarkers. 2010;15(1):52-60. https://doi.org/10.3109/13547500903276378 PMid:19811113

39. Lionetto MG, Caricato R, Calisi A, Giordano ME, Schettino T. Acetylcholinesterase as a biomarker in environmental and occupational medicine: New insights and future perspectives. Biomed Res Int. 2013;2013:321213. https://doi. org/10.1155/2013/321213

PMid:23936791

40. Wiryadana KA, Supadmanaba IG, Samatra ID. Progress and potential roles blood biomarkers of ischemic stroke in clinical setting. Indones J Biomed Sci. 2017;11(2):19-29. https://doi. org/10.15562/ijbs.v11i2.138

41. Mashali A, Howaida A, Gihan M, Manal H. Role of Oxidative Stress and Apoptosis in Acute Organophosphorus Intoxicated 
Patients. J Med Res Inst. 2005;26(3):255-63.

42. Mutalib MA, Rahmat A, Ali F, Othman F, Ramasamy R Nutritional compositions and antiproliferative activities of different solvent fractions from ethanol extract of Cyphomandra betacea (Tamarillo) Fruit. Malays J Med Sci. 2017;24(5):19-32. PMid:29386969

43. Noeman SA, Hamooda HE, Baalash AA. Biochemical study of oxidative stress markers in the liver, kidney and heart of high fat diet induced obesity in rats. Diabetol Metab Syndr. 2011;3(1):17. https://doi.org/10.1186/1758-5996-3-17

PMid:21812977

44. Prior RL. Fruits and vegetables in the prevention of cellular oxidative damage. Am J Clin Nutr. 2003;78(3):570S-8S.

PMid:12936951

45. Mazza G, Kay CD, Cottrell T, Holub BJ. Absorption of anthocyanins from blueberries and serum antioxidant status in human subjects. J Agric Food Chem. 2002;50(26):7731-7. https://doi.org/10.1021/jf020690l

PMid:12475297

46. Chun OK, Chung SJ, Claycombe KJ, Song WO. Serum C-reactive protein concentrations are inversely associated with dietary flavonoid intake in U.S. Adults. J Nutr. 2008;138(4):75360. https://doi.org/10.1093/jn/138.4.753
PMid:18356331

47. Wannamethee SG, Lowe GD, Rumley A, Bruckdorfer KR, Whincup PH. Associations of Vitamin C status, fruit and vegetable intakes, and markers of inflammation and hemostasis. Am J Clin Nutr. 2006;83(3):567-74. https://doi.org/10.1093/ajcn.83.3.567 PMid:16522902

48. Esmaillzadeh A, Kimiagar M, Mehrabi Y, Azadbakht L, Hu FB, Willett WC. Fruit and vegetable intakes, C-reactive protein, and the metabolic syndrome. Am J Clin Nutr. 2006;84(6):1489-97. https://doi.org/10.1093/ajcn/84.6.1489

PMid:17158434

49. Voutilainen S, Nurmi T, Mursu J, Rissanen TH. Carotenoids and cardiovascular health. Am J Clin Nutr. 2006;83(6):1265-71.

PMid:16762935

50. Kris-Etherton PM, Hecker KD, Bonanome A, Coval SM, Binkoski AE, Hilpert KF, et al. Bioactive compounds in foods: Their role in the prevention of cardiovascular disease and cancer. Am J Med. 2002;113(9):71S-88S. https://doi. org/10.1016/s0002-9343(01)00995-0

PMid:12566142

51. Muliarta IM, Adiputra LM, Dinata IM, Adiputra IN. Oral tamarillo juice preventable to decline lung function among parking workers. Int J Sci Res. 2017;6(2):1535-7. 